\title{
Thermal Comfort in a Naturally-Ventilated Educational Building
}

\author{
David Mwale Ogoli
}

Judson College, Elgin, IL

\begin{abstract}
A comprehensive study of thermal comfort in a naturally ventilated education building $\left(88,000 \mathrm{ft}^{2}\right)$ in a Chicago suburb will be conducted with 120 student subjects in 2007 . This paper discusses some recent trends in worldwide thermal comfort studies and presents a proposal of research for this building through a series of questionnaire tables. Two research methods used in thermal comfort studies are field studies and laboratory experiments in climate-chambers. The various elements that constitute a "comfortable" thermal environment include physical factors (ambient air temperature, mean radiant temperature, air movement and humidity), personal factors (activity and clothing), classifications (gender, age, education, etc.) and psychological expectations (knowledge, experience, psychological effect of visual warmth by, say, a fireplace). Comparisons are made using data gathered from Nairobi, Kenya.
\end{abstract}

Keywords: Comfort, temperature, humidity and ventilation

\section{INTRODUCTION}

The "comfort zone" is an appropriate design goal for a deterministic mechanical system but analysis of many international field studies by researchers has questioned its relevance to passive solar buildings (Humphreys, 1976; Auliciems, 1978; Forwood, 1995; Baker and Standeven, 1996; Standeven and Baker, 1995; Milne, 1995;). Givoni (1998) revised his already authoritative and notable work on the building bio-climatic chart having recognized this new position. These revisions reflect a paradigm shift in thermal comfort for people relative to their thermal environment. The American Society of Heating, Ventilating and Air-conditioning Engineers (ASHRAE) has been discussing how people adapt to higher indoor temperatures in naturally ventilated buildings (Olesen, 2000).

There is mounting evidence (Humphreys, 1996; Karyono, 2000) that confirms that thermal perceptions are affected by factors that are not recognized by current comfort standards. The factors include thermal history, non-thermal stimuli and psychological expectations. These perceptions are most noticeable in naturally ventilated buildings where expectations are distinctly different from air-conditioned buildings. Mclntyre (1980) stated that "a person's reaction to a temperature which is less than perfect will depend very much on his expectations, personality and what else he is doing at the time". A study (Brager and de Dear, 1998) noted that "anecdotal evidence suggests that building occupants become accustomed to levels of warmth prevailing within buildings on time scales of weeks to months". They concluded that there is a distinction between thermal comfort responses in air-conditioned vs. naturally ventilated buildings. It leads to another emerging observation of psychological adaptation resulting from one's thermal experiences and expectations. Psychologically, people perceive or respond to the thermal experiences in apparently altered manner. Paciuk (1990) and Williams (1995) found that perceived degree of control is one of the strongest predictors of thermal comfort. Leaman and Bordass (1999), Bunn (1993), Raja et al. (2001) and Brager (2000) documented that people who have greater control over their indoor environment are more tolerant of wider ranges in temperature. These "adaptive errors" are the cause of discrepancy between observed comfort temperatures from field studies and predicted comfort temperatures from climate chamber experiments.

\section{THERMAL COMFORT STUDIES}

\subsection{Climate-chamber studies and thermal comfort scales}

The climate chamber is based on a heat-balance model whereby subjects in a carefully controlled environment are subjected to different levels of physical environmental parameters and their "neutral" heat balance point established. Pioneer thermal comfort work by International Standards Organization (ISO), ASHRAE (2005) and Fanger (1969) was based on this model. Subjects in the comfort studies were asked to judge the conditions 
(preferred temperature) in a space and record it using the ASHRAE thermal sensation numerical scale shown in Table 1. Other commonly used scales are shown in Tables 2-4.

Table 1: ASHRAE Thermal Comfort Scale

\begin{tabular}{c|c|c|c}
\hline Question & Scale & Thermal sensation & Vote \\
\hline \multirow{4}{*}{$\begin{array}{c}\text { How do you feel } \\
\text { about the } \\
\text { thermal }\end{array}$} & +3 & Hot & \\
\cline { 2 - 4 } environment in \\
\cline { 2 - 4 } this room? & +2 & Warm & \\
\cline { 2 - 4 } & 0 & Comfortable, neutral & \\
\cline { 2 - 4 } & -1 & Slightly cool & \\
\cline { 2 - 4 } & -2 & Cool & \\
\hline
\end{tabular}

Source: ASHRAE Standard 55-2004:5

Table 2: McIntyre Scale

\begin{tabular}{c|c|c}
\hline Question & Response & Vote \\
\hline \multirow{2}{*}{ I would like to be. ... } & Cooler & \\
\cline { 2 - 3 } & No change & \\
\cline { 2 - 3 } & Warmer & \\
\hline
\end{tabular}

Source: Humphreys 1996:140

Table 3: Humidity Scale

\begin{tabular}{c|c|c|c}
\hline Question & Scale & Thermal sensation & Vote \\
\hline \multirow{4}{*}{$\begin{array}{c}\text { How do you feel } \\
\text { about the } \\
\text { humidity in this } \\
\text { room? }\end{array}$} & +3 & Much too dry & \\
\cline { 2 - 4 } & +2 & Too dry & \\
\cline { 2 - 4 } & 0 & Slightly dry & \\
\cline { 2 - 4 } & -1 & Comfortable, neutral & \\
\cline { 2 - 4 } & -2 & Slightly humid & \\
\cline { 2 - 4 } & -3 & Much too humid & \\
\hline
\end{tabular}

Source: Humphreys 1996:140

Table 4: Air movement Scale

\begin{tabular}{c|c|c|c}
\hline Question & Scale & Thermal sensation & Vote \\
\hline \multirow{4}{*}{$\begin{array}{c}\text { How do you feel } \\
\text { about the air } \\
\text { movement in this } \\
\text { room? }\end{array}$} & +3 & Much too still & \\
\cline { 2 - 4 } & +2 & Too still & \\
\cline { 2 - 4 } & 0 & Slightly still & \\
\cline { 2 - 4 } & -1 & Comfortable, neutral & \\
\cline { 2 - 4 } & -2 & Too breezy & \\
\hline
\end{tabular}

Source: De Dear and Brager, 1998

Climate-chamber studies done in the 1970's at the Institute for Environmental Research at Kansas State University by Rohles and Nevins (1971) and Rohles (1973) showed that there are correlations between comfort level, temperature, humidity, sex, and length of exposure. Rohles (1980) concluded: "To deny or ignore the psychology involved in comfort measurement is not only shortsighted, but treats the human subject as a machine, which it is not". Rohles (1981) also indicated that alongside control of physical variables, adjustments in the amount of furnishing in a space and lighting levels could probably provide a solution to improving thermal comfort. Their results, with various equations for predicting thermal sensation, have been published in ASHRAE Handbook of Fundamentals (2005:8.12).

While climate chambers lack the realism of an actual building and are unsuitable for longitudinal studies (those in which the thermal experience of a relatively small number of subjects is monitored over a period of time) or 
transverse surveys (those in which a larger group of subjects, being a more representative sample of the population, is polled on a smaller number of occasions but with less information on each subject), they are nonetheless useful tools due to their high degree of control and reproducibility. These methods (longitudinal and transverse) are most suitable in field studies.

\subsection{Field studies}

Humphreys (1975) in summarizing 36 previous field studies on comfort in different countries derived a formula correlating comfort temperatures $\left(T_{c o}\right)$ with mean monthly outdoor air or globe temperature $\left(T_{m}\right)$ of the location:

$\mathrm{T}_{\mathrm{co}}=2.56+0.831\left(\mathrm{~T}_{\mathrm{m}}\right)\left({ }^{\circ} \mathrm{C}\right)$

Humphreys (1978) also compared "free-running" buildings (passive and naturally ventilated) with mechanically controlled buildings. He observed that:

$\mathrm{T}_{\mathrm{co}}=11.9+0.534\left(\mathrm{~T}_{\mathrm{m}}\right)\left({ }^{\circ} \mathrm{C}\right)\left(\right.$ passive solar building ranging between $\left.10 \leq \mathrm{T}_{\mathrm{m}} \leq 34^{\circ} \mathrm{C}\right)$

$\mathrm{T}_{\mathrm{co}}=0.0065\left(\mathrm{~T}_{\mathrm{m}}\right)^{2}+0.32\left(\mathrm{~T}_{\mathrm{h}}\right)+12.4\left({ }^{\circ} \mathrm{C}\right)$ (mechanical-systems building ranging $-24 \leq \mathrm{T}_{\mathrm{m}} \leq 23^{\circ} \mathrm{C}$ and $\left.18 \leq \mathrm{T}_{\mathrm{h}} \leq 30^{\circ} \mathrm{C}\right)$

Where $T_{h}$ is the average daily maximum temperature of the hottest months of the year

Nicol and Roaf (1996) proposed an adaptive algorithm suitable for determining comfort temperatures ( $\left.T_{\text {co }}\right)$ in Pakistan. It used simple outdoor temperature calculated from the preceding month $\left(T_{m^{\prime}}\right)$ :

$\mathrm{T}_{\mathrm{co}}=17.0+0.38\left(\mathrm{~T}_{\mathrm{m}}\right)\left({ }^{\circ} \mathrm{C}\right)$ (passive solar building)

A similar relationship of comfort temperature on mean outdoor temperature by Auliciems and de Dear (1978) is:

$\mathrm{T}_{\mathrm{co}}=17.6+0.31\left(\mathrm{~T}_{\mathrm{m}}\right)\left({ }^{\circ} \mathrm{C}\right)$ (passive solar building)

The above algorithms were made in studies done under "free-running", or natural or passive solar conditions in various climates. There are limitations to using these equations in differing locations like Chicago, IL or Nairobi, Kenya, because of the differences of latitude, altitude, geography, climate and the need to establish a localized thermal comfort standard. Climatic conditions for equatorial highland regions tend to be generally the same all year round (Ogoli, 2000). As an example, using outdoor temperature in Nairobi and the above stated equations for passive solar buildings, the following speculative comfort temperatures in Table 5 were established for the hottest month (February):

Table 5: Comfort temperatures in February for Nairobi, Kenya

\begin{tabular}{c|cccc}
\hline & Observed & Humphreys & Nicol and Roaf & Auliciems De Dear \\
\hline${ }^{\circ} \mathrm{F}$ & 71.1 & 74.3 & 77.4 & 75.7 \\
\hline${ }^{\circ} \mathrm{C}$ & 21.7 & 23.5 & 25.2 & 24.3 \\
\hline
\end{tabular}

\subsection{Adaptive "errors" in thermal comfort}

Humphreys defined comfort as "the absence of discomfort, and discomfort is alleviated by making adjustments". $\mathrm{He}$ is a strong proponent of the adaptive model, i.e. thermal neutrality can be attained by more human involvement rather than just more mechanical controls. Thermal neutrality is a temperature at which a sample population feels neither too hot nor too cold. Field studies on adaptive models have shown that thermal neutrality is a function of the climate that people are acclimatized to. Researchers are increasingly questioning whether the simplistic cause-and-effect approach embodied in these laboratory-derived models can be applied, without modification, to describe real-world thermal perception.

The adaptive model is the most effective way of assessing passive solar buildings, or what is sometimes called free-running buildings. The adaptive models allows people to make adjustments to their clothing, activity, posture, eating or drinking, shifting position in a room, operating a window or shading device, or other adaptive opportunity in order to achieve or maintain thermal comfort. It appears that when people are allowed greater adjustment and control over their own indoor environment, it extends the comfort zone. The adaptive model acknowledges that the occupant is not just a passive recipient of the environment but an active member. 


\section{OBSERVATIONS}

Many studies are now being undertaken to establish thermal comfort standards around the world. Even ASHRAE commissioned a project to collect field-study data worldwide to relate comfort temperature and climate. There are limitations to using the previously stated models because "The use of ISO-PMV could lead to unnecessary cooling in warm climates and unnecessary heating in cool ones, and if applied in developing countries would lead to needless economic and environmental penalty" (Humphreys, 1996:142). A survey in Zambia in central Africa between latitudes $8^{\circ}$ and $18^{\circ}$ south, established the comfort temperature as $22.2^{\circ} \mathrm{C}$, and comfort zone as 19.7-24. $7^{\circ} \mathrm{C}$ for the cool season; ASHRAE Standard 55 overestimates the lower comfort limit for this region by $2.7^{\circ} \mathrm{C}$ (Sharples and Mulama, 1997).

A recent study (Ogoli, 2000) was undertaken in Nairobi, Kenya, to observe indoor temperatures in passive solar buildings with different amounts of thermal mass. The stratified indoor temperatures in light mass building (Figure 1) and high mass building (Figure 2) are shown below. The low mass building was made of timber walls and galvanized corrugated iron ( $\mathrm{GCl}$ ) sheet roof while the high mass building was made of stone walls with concrete tile roof. These figures illustrate that the proper use of thermal mass can control indoor temperatures that in turn allow more "adaptive" adjustments for occupants. Temperatures in the low mass building generally follow the outdoor trends. In the case of the high mass building, indoor temperatures remain relatively in a narrow band, thus increasing the potential of thermal comfort through adaptation. A follow-up study (Ogoli, 2002) was made in the prediction of indoor temperatures of closed buildings with high thermal mass.

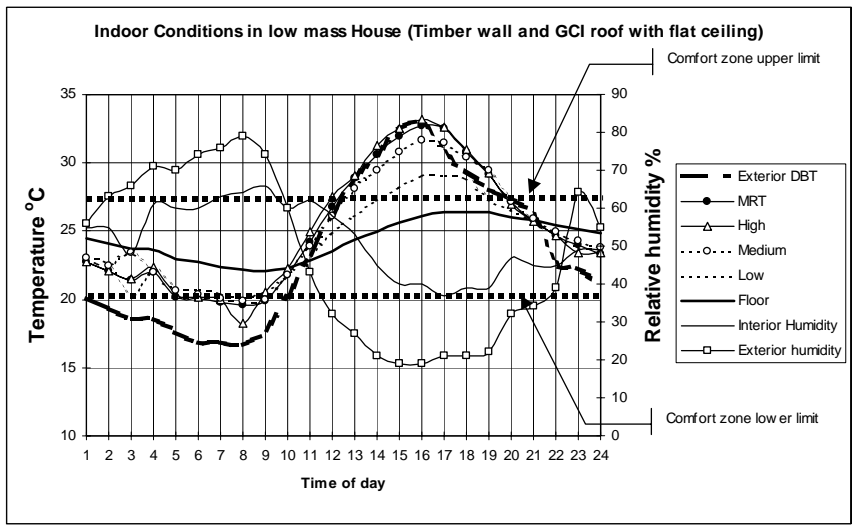

Figure 1: Conditions in a low mass building in Nairobi

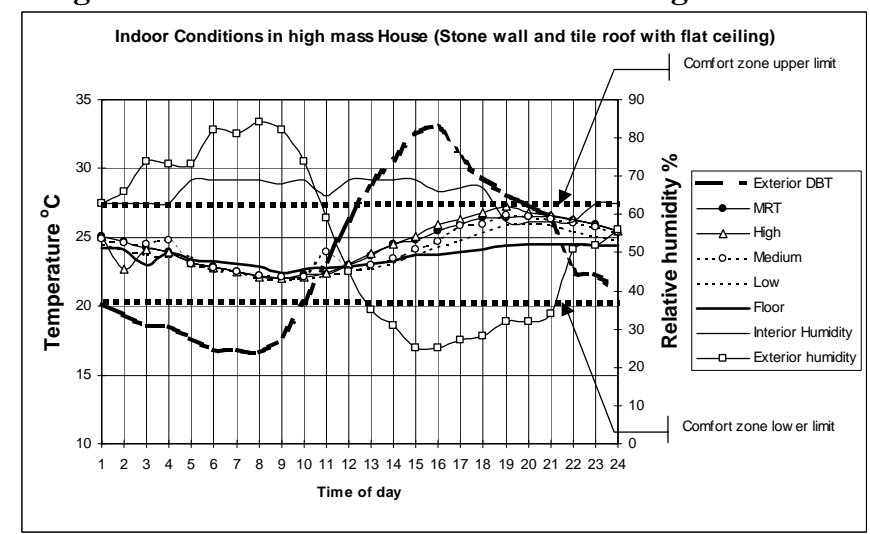

Figure 2: Conditions in a high mass building in Nairobi

\section{ANALYSIS AND DISCUSSION}

\subsection{Proposal for thermal comfort studies (Questionnaires)}

To fully determine the thermal comfort conditions in a given environment, there are a number of questions that should be administered to correct "adaptive errors" that account for the discrepancy between observed comfort temperatures from field studies and predicted comfort temperatures from climate chamber experiments. Five questions from precious studies that need to be asked are:

1. How do you feel about the thermal environment in this room?

2. Is the present environment acceptable? 
3. Would you prefer some mechanical ventilation and air-conditioning?

4. What personal adjustment(s) have you made to yourself or to the room?

5. At the present moment would you like more, less, or no change in the level of air movement in this room?

These questions may be administered half hourly alongside the process of taking accurate measurements of the thermal environment. Tables 6-10 are an example for a proposed layout for a trial example of a 3-hour period. The tables are formulated using current technical literature and anecdotal evidence.

Table 6: How do you feel about the thermal environment in this room?

\begin{tabular}{|c|c|c|c|c|c|c|c|}
\hline \multirow{2}{*}{$\begin{array}{l}\text { Thermal } \\
\text { Sensation }\end{array}$} & \multirow[t]{2}{*}{ Vote } & \multicolumn{6}{|c|}{ Hour } \\
\hline & & $1 / 2$ & 1 & $1 \frac{1}{2}$ & 2 & $2 \frac{1}{2}$ & 3 \\
\hline $\mathrm{Hot}$ & +3 & & & & & & \\
\hline Warm & +2 & & & & & & \\
\hline Slightly warm & +1 & & & & & & \\
\hline Neutral & \pm 0 & & & & & & \\
\hline Slightly cool & -1 & & & & & & \\
\hline Cool & -2 & & & & & & \\
\hline Cold & -3 & & & & & & \\
\hline
\end{tabular}

Table 7: Is the present thermal environment acceptable?

\begin{tabular}{c|ccccccc}
\hline Response & Score & \multicolumn{7}{c}{ Hour } \\
\cline { 2 - 7 } & & $1 / 2$ & 1 & $1 \frac{1}{2} 2$ & 2 & 2 & \\
\hline Yes & 1 & & & & & & \\
No & 0 & & & & & & \\
\hline
\end{tabular}

Table 8: Would you prefer some mechanical ventilation and air-conditioning?

\begin{tabular}{c|ccccccc}
\hline Response & Score & \multicolumn{7}{c}{ Hour } \\
\cline { 2 - 7 } & & $1 / 2$ & 1 & $11 / 2$ & 2 & $21 / 2$ & 3 \\
\hline Cooler & -1 & & & & & & \\
None & 0 & & & & & & \\
Warmer & 1 & & & & & & \\
\hline
\end{tabular}

Table 9: What personal adjustment(s) have you made to yourself or to the room?

\begin{tabular}{|c|c|c|c|c|c|c|c|}
\hline \multirow[t]{2}{*}{ Response } & \multirow{2}{*}{$\begin{array}{l}\text { Score } \\
\text { Range }\end{array}$} & \multicolumn{6}{|c|}{ Hour } \\
\hline & & $1 / 2$ & 1 & $11 / 2$ & 2 & $2 \frac{1}{2}$ & 3 \\
\hline Clothing & 1 to 10 & & & & & & \\
\hline Activity & 1 to 10 & & & & & & \\
\hline Posture & 1 to 10 & & & & & & \\
\hline Eat/drink & 1 to 10 & & & & & & \\
\hline Moved & 1 to 10 & & & & & & \\
\hline Heat/cool & 1 to 10 & & & & & & \\
\hline Window & 1 to 10 & & & & & & \\
\hline
\end{tabular}

Table 10: At the present moment would you like more, less, or no change in the level of air movement in this room?

\begin{tabular}{|c|c|c|c|c|c|c|c|}
\hline & \multirow[t]{2}{*}{ Score } & \multicolumn{6}{|c|}{ Hour } \\
\hline & & $1 / 2$ & 1 & $1 \frac{1}{2}$ & 2 & $2 \frac{1 / 2}{2}$ & 3 \\
\hline $\begin{array}{c}\text { Less air } \\
\text { No change } \\
\text { More air }\end{array}$ & $\begin{array}{c}-1 \\
0 \\
+1\end{array}$ & & & & & & \\
\hline
\end{tabular}


The physical parameters that should be measured alongside the questionnaire include ambient air temperature, mean radiant temperature, air movement and humidity. The instruments should be accurate enough that meet specifications for accuracy and response times described by ISO Standard 7726 and/or ANSI/ASHRAE Standard 55-1992, shown in Table 11.

Table 11: Measuring range and accuracy of instruments

\begin{tabular}{c|ccc}
\hline Parameter & Measuring Range & Accuracy & Response Time (90\%) \\
\hline Dry Bulb Temperature & $5-40^{\circ} \mathrm{C}\left(39-104^{\circ} \mathrm{F}\right)$ & $\pm 0.2^{\circ} \mathrm{C}\left( \pm 0.4^{\circ} \mathrm{F}\right)$ & Appropriate \\
Wet Bulb Temperature & $5-40^{\circ} \mathrm{C}\left(39-104^{\circ} \mathrm{F}\right)$ & $\pm 0.2^{\circ} \mathrm{C}\left( \pm 0.4^{\circ} \mathrm{F}\right)$ & Appropriate \\
Mean Radiant & $5-40^{\circ} \mathrm{C}\left(39-104^{\circ} \mathrm{F}\right)$ & $\pm 0.2^{\circ} \mathrm{C}\left( \pm 0.4^{\circ} \mathrm{F}\right)$ & Appropriate \\
Temperature & $0.05-0.5 \mathrm{~m} / \mathrm{s}(10-100$ & $\pm 0.5^{\circ} \mathrm{C}\left( \pm 1.0^{\circ} \mathrm{F}\right)$ & $1-10$ seconds \\
Air Speed & $\mathrm{fpm})$ & \multicolumn{2}{c}{}
\end{tabular}

\subsection{Observations from other studies}

Thermal comfort is a complex phenomenon, which is influenced by several parameters: environmental (physical), personal and psychological. Two of the most common ways to quantitatively expressing thermal comfort and thermal sensation is Predicted Mean Vote (PMV) and Predicted Percent Dissatisfied (PPD) after Fanger (1970). However, there have been several field studies that do not agree with the results of this method, especially in passive solar buildings.

Several extensive field studies summarized by De Dear and Brager (1998) show that the PMV model works best in buildings that have HVAC systems. The studies also show that in naturally ventilated buildings (free running with no mechanical systems) people seem to adapt (behavioral, psychological) and can accept "higher indoor temperatures than predicted by the PMV model" (Olesen, 2000:44).

Givoni defined thermal comfort as "the range of climatic conditions considered comfortable and acceptable inside buildings. It implies an absence of any sensation of thermal (heat or cold) discomfort" (Givoni, 1998:3). In 1976 he developed the building bio-climatic chart to address the problems associated with the charts by Olgyay. It was based on indoor temperatures and suggested boundaries of the climatic conditions on the psychrometric chart within which various building design strategies (including passive and low energy cooling systems) could provide indoor comfort in hot climates without air-conditioning. The boundaries of acceptable conditions for still air are shown on the psychrometric chart in Figure 3. They were extended due to the effect of adaptive factors.

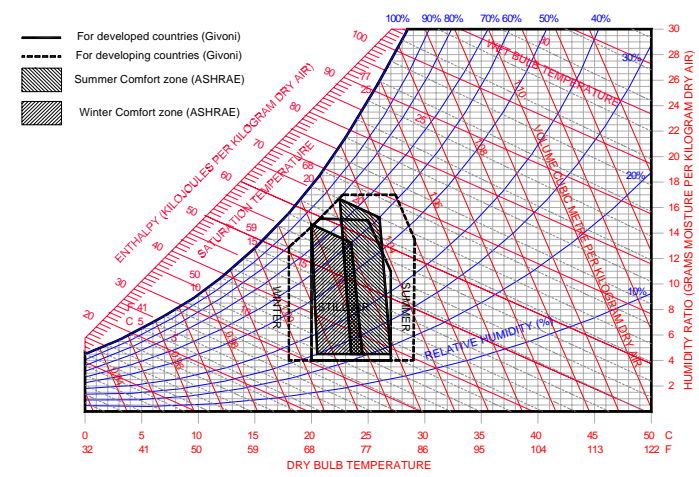

Figure 3: Boundaries of comfort conditions

Source: (Givoni, 1998: 38)

Brager and de Dear in 1996 noted that field studies show that the two most widely used thermal comfort standards (ISO Standard 7730 and ASHRAE Standard 55) do not account for the effects of expectation, personal control and psychological adaptation. In fact, they discourage the use of naturally ventilated passive solar buildings because of the narrow band of comfort limits. Occupants in passive solar buildings have more relaxed expectations and can tolerate a wider temperature swing. On the other hand, occupants of airconditioned buildings have a narrow rigid thermal environment and are more sensitive to thermal environments.

\section{CONCLUSION}

Thermal comfort in Nairobi or Chicago may offer insight on the fact people with different expectations, culture and history all require thermal comfort. Adaptive factors may be more easily visible in a low-tech society but even in industrialized countries, they offer an opportunity for modern usage. The universality hypothesis of comfort 
temperatures based on ISO Standard 7730 and ASHRAE Standard 55-92 extrapolated as equally applicable to human beings around the world regardless of race, culture or climatic experience were the central theme of a strong argument made by Madhavi and Kumar (1996). Fanger in his work used a small group of "tropical travelers" winter swimmers and meat packers in two experiments in Copenhagen, Denmark, to derive the PMV. The sample size used was statistically too small and Auliciems succinctly put that: "It is not often realized that the claims of its universal applicability were based on remarkably limited and rather incompletely reported preference studies of only 16 travelers from Copenhagen and 32 Danes" (Auliciems, 1989:18). This article is a preparation for further research of thermal comfort in a new naturally-ventilated academic building $\left(88,000 \mathrm{ft}^{2}\right)$ to be completed in spring 2007 on the College campus.

\section{ACKNOWLEDGEMENT}

Author wishes to give many thanks to the staff, faculty and students of architecture at Judson College.

\section{REFERENCES}

ANSI/ASHRAE.1992. Thermal Environmental Conditions for Human Occupancy ANSI/ASHRAE Standard 551992. American Society of Heating, Ventilating and Air-conditioning Engineers, Inc.: Atlanta, GA.

ANSI/ASHRAE. 2004. Thermal Environmental Conditions for Human Occupancy ANSI/ASHRAE Standard 552004. American Society of Heating, Ventilating and Air-conditioning Engineers, Inc.: Atlanta, GA.

ASHRAE. 2005. Handbook of Fundamentals. American Society of Heating, Ventilating and Air-conditioning Engineers, Inc.: Atlanta, GA.

Auliciems, A. 1989. Thermal Comfort in Building Design and Human Performance by N. C. Ruck (ed). Van Nostrand Reinhold: New York.

Auliciems, A. and Richard de Dear. 1978. "Air conditioning in Australia, I. Human thermal factors", in Architectural Science Review 29 (1978) 67-75.

Baker, Nick and Mark Standeven. 1996. "Thermal Comfort in Free-Running Buildings" in Energy and Buildings, 23 (1996) 175-182.

Brager, Gail Schiller. 2000. "A Standard for natural ventilation" in ASHRAE Journal, October 2000, page 21-27. American Society of Heating, Refrigerating and Air Conditioning Engineers Inc.: Atlanta GA.

Brager, Gail S. and Richard J. de Dear. 1998. "Thermal adaptation in the built environment: a literature review" in Energy and Buildings 27 (1998) 83-96.

Bunn, R. 1993. "Fanger: Face to face" in Building Services, June, 25-27, 1993.

De Dear, R. and Brager, G. S. 1998. "Developing an adaptive model of thermal comfort and preference" in ASHRAE Transactions 104 (1).

Fanger, P. O. 1967. "Calculation of thermal comfort: introduction of a basic comfort equation" in ASHRAE Transactions 73 (2): III.4.1.

Fanger, P. O. 1970. Thermal Comfort: Analysis and Applications in Environmental Engineering. McGraw-Hill Book Company: New York

Forwood, G. 1995. "What is thermal comfort in a naturally ventilated building?" in: Nicol, Humphreys, Sykes, Roaf (eds.) Thermal Comfort. London: E and F. N. Spoon 1995, pp. 122-131.

Givoni, Baruch. 1998. Climate Considerations In Building And Urban Design. John Wiley \& Sons, New York

Humphreys, Reverend Michael A. 1976. "Field Studies of thermal comfort compared and applied" in Building Services Engineer, 44, pp. 5-27

Humphreys, Reverend Michael A. 1996. "Thermal comfort temperatures world-wide - The current position" in Renewable Energy, Vol. 8 Issues 1-5 May 1996, pp. 139-144.

Humphreys, Reverend Michael A. 1975. "Field Studies of thermal comfort compared and applied", Building Research Establishment, Current Paper. CP 76/75, Garston, Watford, UK. 
Humphreys, Reverend Michael A. 1978. "Outdoor temperatures and comfort indoors" in Building Research and Practice, 62, pp. 92-105.

ISO 7730. 1994. ISO Standard 7730: Moderate Thermal Environments - Determination of the PMV and PPD Indices and Specification of the Conditions for Thermal Comfort. International Standards Organization: Geneva.

Karyono, Tri Harso. 2000. "Report on thermal comfort and building energy studies in Jakarta" in Building and Environment 35 (2000) 77-90.

Leaman, Adrian and Bill Bordass. 1999. "Productivity in buildings: the 'killer' variables", Building Research \& Information (1999) 27 (1), 4-19.

Mahdavi, Ardeshir and Satish Kumar. 1996. Implications of indoor climate control for comfort, energy and environment in Energy and Buildings, 24 (1996) 167-177. Elsevier Science Limited: Amsterdam

Mclntyre, D. A. 1980. "Design requirements for a comfortable environment" in Bio-engineering, Thermal Physiology and Comfort by K. Cena, J. A. Clark (eds), pp. 157-168.

Milne, G. R. 1995. "The energy implications of a climate-based indoor air temperature standard" in Standards for Thermal Comfort: Indoor air temperatures for the $21^{\text {st }}$ century pp. 182-189 by F. Nicol, M. Humphreys, O. Sykes and S. Roaf (eds). E \& FN Spon: London.

Nicol, J. Fergus and Susan Roaf. 1996. "Pioneering new indoor temperature standards: the Pakistan project" in Energy and Buildings, 23 (1996) 169-174. . Elsevier Science Limited: Amsterdam

Ogoli, David Mwale. 2000. Energy-efficiency and Comfort Conditions in Passive Solar Buildings at Equatorial High Altitudes, Ph.D. Dissertation. University of Florida: Gainesville, FL.

Ogoli, David Mwale. 2002. "Predicting indoor temperatures in nclosed buildimngs with high thermal mass" in Energy and Buildings, 35 (2002) 851-862. Elsevier Science Limited: Amsterdam

Rohles, F. H. 1973. "The revised modal comfort envelope" in ASHRAE Transactions 79 (2):52.

Olesen, Bjarne W. 2000. "Guidelines for comfort" in ASHRAE Journal Vol. 42, No. 8, August 2000.

Paciuk, M. 1990. "The role of personal control of the environment in thermal comfort and satisfaction at the workplace, Coming of age" in Environmental Design Research Association pp. 303-312 by R. I. Selby, K. H. Anthony, J. Choi, B. Orland (eds.), Environmental Design Research Association: Oklahoma City, OK.

Raja, Iftikhar A., Fergus Nicol, Kathryn J.McCartney, Michael A. Humphreys. 2001. "Thermal Comfort: use of controls in naturally ventilated buildings" in Energy and Buildings 33 (2001) 235-244.

Rohles, F. H. 1980. "Temperature or temperament: a psychologist looks at thermal comfort" in ASHRAE Transactions, 86, 541-551.

Rohles, F. H. 1981. "Thermal comfort and strategies for energy conservation" in Journal of Social Issues, 37 , 132-149.

Rohles, F. H. and R. G. Nevins. 1971. "The nature of thermal comfort for sedentary man" in ASHRAE Transactions, 77 (1) pp. 239-246, 1971.

Sharples, Steve and Albert Malama. 1997. "A thermal comfort field survey in the cool season of Zambia" in Building and Environment, Vol. 32, No. 3, pp. 237 - 243, 1997. Elsevier Science Limited: Amsterdam.

Standeven, M. A. and Nick V. Baker. 1995. "Comfort conditions in PASCOOL surveys" in Standards for Thermal Comfort: Indoor air temperatures for the $21^{\text {st }}$ century pp. 161-168 by F. Nicol, M. Humphreys, O. Sykes and S. Roaf (eds). E \& FN Spon: London.

Williams, R. N. 1995. "Field investigation of thermal comfort, environmental satisfaction and perceived controls levels in UK office buildings", Healthy Buildings. 